\title{
Inorganic arsenic levels in baby rice are of concern
}

\author{
Andrew A. Meharg ${ }^{\text {a,* }}$, Guoxin Sun ${ }^{\text {b }}$, Paul N. Williams ${ }^{\text {a,b }}$, Eureka Adomako ${ }^{\text {a }}$, \\ Claire Deacon ${ }^{a}$, Yong-Guan Zhu ${ }^{b}$, Joerg Feldmann ${ }^{c}$, Andrea Raab ${ }^{c}$ \\ ${ }^{\text {a }}$ School of Biological Sciences, University of Aberdeen, Cruickshank Building, St. Machar Drive, Aberdeen AB24 3UU, UK \\ ${ }^{\mathrm{b}}$ Research Centre for Eco-Environmental Sciences, Chinese Academy of Sciences, Beijing 100085, China \\ ${ }^{\mathrm{c}}$ Department of Chemistry, University of Aberdeen, Meston Building, Meston Walk, Aberdeen AB24 $3 U E$, UK
}

Received 30 November 2007; received in revised form 21 January 2008; accepted 27 January 2008

Median consumption of organic arsenic levels for UK babies from baby rice is above threshold considered safe.

\begin{abstract}
Inorganic arsenic is a chronic exposure carcinogen. Analysis of UK baby rice revealed a median inorganic arsenic content $(n=17)$ of $0.11 \mathrm{mg} / \mathrm{kg}$. By plotting inorganic arsenic against total arsenic, it was found that inorganic concentrations increased linearly up to $0.25 \mathrm{mg} /$ $\mathrm{kg}$ total arsenic, then plateaued at $0.16 \mathrm{mg} / \mathrm{kg}$ at higher total arsenic concentrations. Inorganic arsenic intake by babies (4-12 months) was considered with respect to current dietary ingestion regulations. It was found that $35 \%$ of the baby rice samples analysed would be illegal for sale in China which has regulatory limit of $0.15 \mathrm{mg} / \mathrm{kg}$ inorganic arsenic. EU and US food regulations on arsenic are non-existent. When baby inorganic arsenic intake from rice was considered, median consumption (expressed as $\mu \mathrm{g} / \mathrm{kg} / \mathrm{d}$ ) was higher than drinking water maximum exposures predicted for adults in these regions when water intake was expressed on a bodyweight basis.
\end{abstract}

(C) 2008 Elsevier Ltd. All rights reserved.

Keywords: Arsenic; Baby rice; Food regulations

\section{Introduction}

One-year-old weaned babies' hair arsenic content was found to be 10-fold greater than 1-month-old infants (Gibson and Cage, 1982). Infant formulae fed babies had higher hair arsenic contents than breast-fed counterparts due to earlier introduction to weaning, with cereals being the most elevated source of arsenic in weaning diets (Gibson and Cage, 1982). Rice has higher grain arsenic levels than other investigated cereals (wheat and barley) as it is much more efficient in accumulating arsenic from the soil (Williams et al., 2007b). Pre-cooked, milled rice is a dominant carbohydrate source to weaning babies up to 1 year of age due to a range of its blandness, material properties, low allergen potential and nutritional value (Mennella et al., 2006).

\footnotetext{
* Corresponding author.

E-mail address: a.meharg@abdn.ac.uk (A.A. Meharg).
}

Inorganic arsenic is a chronic exposure carcinogen (IARC, 2004; NRC, 2001). For populations not exposed through elevated drinking water, rice is the primary dietary source of inorganic arsenic (Meacher et al., 2002; Meliker et al., 2006; Tsuji et al., 2007). Inorganic arsenic exposure through baby foods has received less attention. Tsuji et al. (2007) has modelled baby inorganic arsenic exposure based on levels found in a limited survey $(n=4)$ of polished grain, but not baby rice per se.

This study established inorganic arsenic content in a range of UK purchased baby rice samples. It then extrapolated this information to calculate inorganic arsenic intake on a daily basis for weaning babies so that this exposure could be placed in context with respect to dietary arsenic regulations.

\section{Materials and methods}

All baby rice samples were obtained from national supermarket chains in the city of Aberdeen, UK during winter of 2006. Three specific brands 
covering 3 manufacturers were commonly found, and one sample from each supermarket chain visited was sampled, if present. Only pure baby rice formulae were sampled rather than the range of amended baby rice products also available. From packaging it could be ascertained that the baby rice was made either in the UK or EU, but no specific information on the source of the rice grain used was recorded.

The methodologies used here are those previously published for total arsenic (ICP-MS) and arsenic speciation (HPLC-ICP-MS) by Williams et al. (2006). As for those papers powdered rice NIST CRM 1568a was used with each batch to monitor analytical performance, and the results from this NIST reference material were within the ranges reported by Williams et al. (2005, 2006).

\section{Results and discussion}

Data for arsenic speciation and total arsenic concentrations for baby rice are ranked by their inorganic arsenic concentration in Table 1. Inorganic arsenic levels in pure baby rice ranged from 0.06 to 0.16 , with a median of $0.11 \mathrm{mg} / \mathrm{kg}$. These levels are high, for example $35 \%$ of the baby rice samples would be illegal for sale in China, which has a food standard limit of $0.15 \mathrm{mg} / \mathrm{kg}$ inorganic arsenic (USDA, 2006). There is currently no EU or US regulations regarding arsenic levels in foods (Francesconi, 2007). A level of $1 \mathrm{mg} / \mathrm{kg}$ is often cited in the literature as being a safe level for arsenic in foods, and specifically for rice (i.e. Das et al., 2004). This is the UK standard set back in 1959 (The Stationary Office, 1959), 4 decades before national and international health organizations published comprehensive reviews of inorganic arsenic's chronic carcinogenicity (NRC, 2001; IARC, 2004).

The toxicology of arsenic is independent of source once arsenic crosses the gut membrane. All indications are that the bioavailability of inorganic arsenic from rice is high, is in the order of $90 \%$ (Ackerman et al., 2005; Juhasz et al., 2006). Food standards are out of step with drinking water regulations which have received recent revision. EU and US drinking regulations are set at $0.01 \mathrm{mg} / \mathrm{L}$ for "total" and "inorganic" arsenic, respectively, and both assume a daily consumption of $1 \mathrm{~L}$ drinking water per day (CEC, 1998; NRC, 2001). These figures equate to a predicted maximum arsenic intake of $0.17 \mu \mathrm{g} / \mathrm{d} / \mathrm{kg}$ for a conservative body mass of $60 \mathrm{~kg}$. The median intake for a 1-year-old baby of $9.25 \mathrm{~kg}$ (the average of the median weight for a boy and a girl) is $0.21 \mu \mathrm{g} / \mathrm{d} / \mathrm{kg}$. At median exposure infants are receiving more arsenic in their diet than the maximum level assumed under EU/US law, if arsenic consumption is expressed on a bodyweight basis. This calculation was based on the assumption that only one $20 \mathrm{~g}$ portion of baby rice was consumed per day. Baby rice is often packed in 20-25 g sachets for a single serving. If additional servings are given, inorganic arsenic consumption is simply multiplied by the number of servings. For a child eating 3 servings per day their arsenic consumption would be 3.7-fold higher than the maximum assumed under EU/US regulations. For the maximum inorganic arsenic concentration found in baby rice in the UK market this value rises to 6-fold.

Assuming a single $20 \mathrm{~g}$ portion consumption per day, this equates to $4.2 \mu \mathrm{g} / \mathrm{d}$ at median and $6.8 \mu \mathrm{g} / \mathrm{d}$ at the 95 th percentile inorganic arsenic levels reported in Table 1. Tsuji et al. (2007) modelled US toddlers (1-6) and found that, for populations exposed to $<0.01 \mathrm{mg} / \mathrm{L}$ inorganic arsenic in drinking water, mean consumption of inorganic arsenic was below $1 \mu \mathrm{g} / \mathrm{d}$, while at the 95th percentile this figure was $<4 \mu \mathrm{g} / \mathrm{d}$. Therefore, UK babies have much higher inorganic arsenic intakes than US 1-6 year olds. They also have much lower body masses. Tsuji et al. (2007) reported rice consumption rates for US $<1$-year-old babies and found intakes just above $20 \mathrm{~g} / \mathrm{d}$ per rice user (consumer), with an overall average of circa $10 \mathrm{~g}$ rice consumption per capita. In our modelling of rice intake, we used a baby at 1 year old, while Tsuji et al.'s (2007) data refer to all babies. Weaning starts around 4 months old (Mennella et al., 2006). Also, bodyweight increases by around $50 \%$ between 4 and 12 months. Rice consumption data must be viewed in this light.

Table 1

Total arsenic levels and arsenic speciation in baby rice

\begin{tabular}{|c|c|c|c|c|c|c|c|c|c|}
\hline Manufacturer & $\begin{array}{l}\text { Total As } \\
(\mathrm{mg} / \mathrm{kg})\end{array}$ & $\begin{array}{l}\text { Inorg. As } \\
(\mathrm{mg} / \mathrm{kg})\end{array}$ & $\begin{array}{l}\text { DMA } \\
(\mathrm{mg} / \mathrm{kg})\end{array}$ & $\begin{array}{l}\text { Extr. As } \\
(\mathrm{mg} / \mathrm{kg})\end{array}$ & $\begin{array}{l}\text { Col. recov. } \\
(\%)\end{array}$ & $\begin{array}{l}\text { Extr. eff. } \\
(\%)\end{array}$ & $\begin{array}{l}\text { Inorg. As } \\
(\%)\end{array}$ & $\begin{array}{l}\text { DMA } \\
(\%)\end{array}$ & $\begin{array}{l}\text { As intake } \\
(\mu \mathrm{g} / \mathrm{kg} / \mathrm{d})\end{array}$ \\
\hline A (organic) & 0.12 & 0.06 & 0.03 & 0.09 & 102.2 & 74.2 & 48.5 & 27.3 & 0.13 \\
\hline A (organic) & 0.13 & 0.06 & 0.04 & 0.10 & 101.9 & 79.6 & 47.4 & 33.7 & 0.13 \\
\hline B & 0.22 & 0.09 & 0.09 & 0.18 & 101.3 & 80.6 & 42.0 & 39.7 & 0.20 \\
\hline A (organic) & 0.16 & 0.09 & 0.09 & 0.18 & 101.0 & 113.1 & 59.8 & 54.4 & 0.20 \\
\hline $\mathrm{C}$ (organic) & 0.17 & 0.10 & 0.06 & 0.16 & 97.3 & 97.3 & 57.4 & 37.3 & 0.21 \\
\hline A (organic) & 0.17 & 0.10 & 0.06 & 0.16 & 98.4 & 96.1 & 57.0 & 37.6 & 0.21 \\
\hline A (organic) & 0.23 & 0.10 & 0.06 & 0.17 & 97.0 & 73.0 & 43.0 & 27.8 & 0.21 \\
\hline A (organic) & 0.16 & 0.10 & 0.03 & 0.13 & 101.5 & 83.6 & 63.2 & 21.7 & 0.21 \\
\hline C (organic) & 0.15 & 0.11 & 0.04 & 0.15 & 98.2 & 95.1 & 68.8 & 24.6 & 0.21 \\
\hline B & 0.22 & 0.12 & 0.05 & 0.18 & 100.7 & 80.1 & 56.8 & 23.9 & 0.27 \\
\hline C (organic) & 0.23 & 0.13 & 0.06 & 0.19 & 100.9 & 82.8 & 57.9 & 25.7 & 0.29 \\
\hline A (organic) & 0.22 & 0.15 & 0.06 & 0.21 & 98.3 & 96.9 & 66.8 & 28.4 & 0.32 \\
\hline B & 0.24 & 0.15 & 0.07 & 0.22 & 98.4 & 93.1 & 63.9 & 27.7 & 0.32 \\
\hline B & 0.44 & 0.15 & 0.23 & 0.39 & 98.5 & 86.8 & 34.0 & 51.5 & 0.32 \\
\hline B & 0.47 & 0.16 & 0.10 & 0.26 & 98.0 & 56.1 & 33.1 & 21.9 & 0.34 \\
\hline B & 0.32 & 0.16 & 0.10 & 0.27 & 98.2 & 82.8 & 49.3 & 32.0 & 0.34 \\
\hline B & 0.31 & 0.16 & 0.11 & 0.27 & 98.4 & 86.6 & 51.1 & 34.1 & 0.34 \\
\hline
\end{tabular}

Arsenic intake was calculated assuming consumption of a single $20 \mathrm{~g}$ packet baby rice per day for a $9.25 \mathrm{~kg}$ ( $1 \mathrm{gear}$ old) baby. 
The WHO has a permissible maximum tolerable daily intake (PMTDI) of inorganic arsenic for drinking water of $2 \mu \mathrm{g}$ arsenic per day per kg bodyweight (WHO, 1993). This PMTDI value equates to consumption of $3 \mathrm{~L}$ water at 0.05 $\mathrm{mg} / \mathrm{L}$ arsenic for a $75-\mathrm{kg}$ person, which in effect is 15 -fold higher than $0.01 \mathrm{mg} / \mathrm{L}$ arsenic, assuming $1 \mathrm{~L}$ daily drinking water ingestion under EU or US law, so is irrelevant.

The relationship between total baby rice arsenic and inorganic arsenic concentration revealed that inorganic arsenic levels in rice increased linearly up to $0.25 \mathrm{mg} / \mathrm{kg}$ of total arsenic, and then plateaued at an inorganic arsenic concentration of around $0.16 \mathrm{mg} / \mathrm{kg}$ inorganic arsenic (Fig. 1). Although the plot of total arsenic against percentage inorganic arsenic shows more scatter there is a trend that in rice samples with high total arsenic concentrations the percentage inorganic arsenic content decreases. This is in agreement with findings for whole and polished rice grain (Meharg et al., 2008).

From the results presented here it is apparent that inorganic arsenic levels in baby rice should be of concern. There is a wide geographic variation in total and inorganic arsenic grain content (Williams et al., 2005, 2006, 2007a,b). By sourcing rice grain from areas with low grain arsenic such
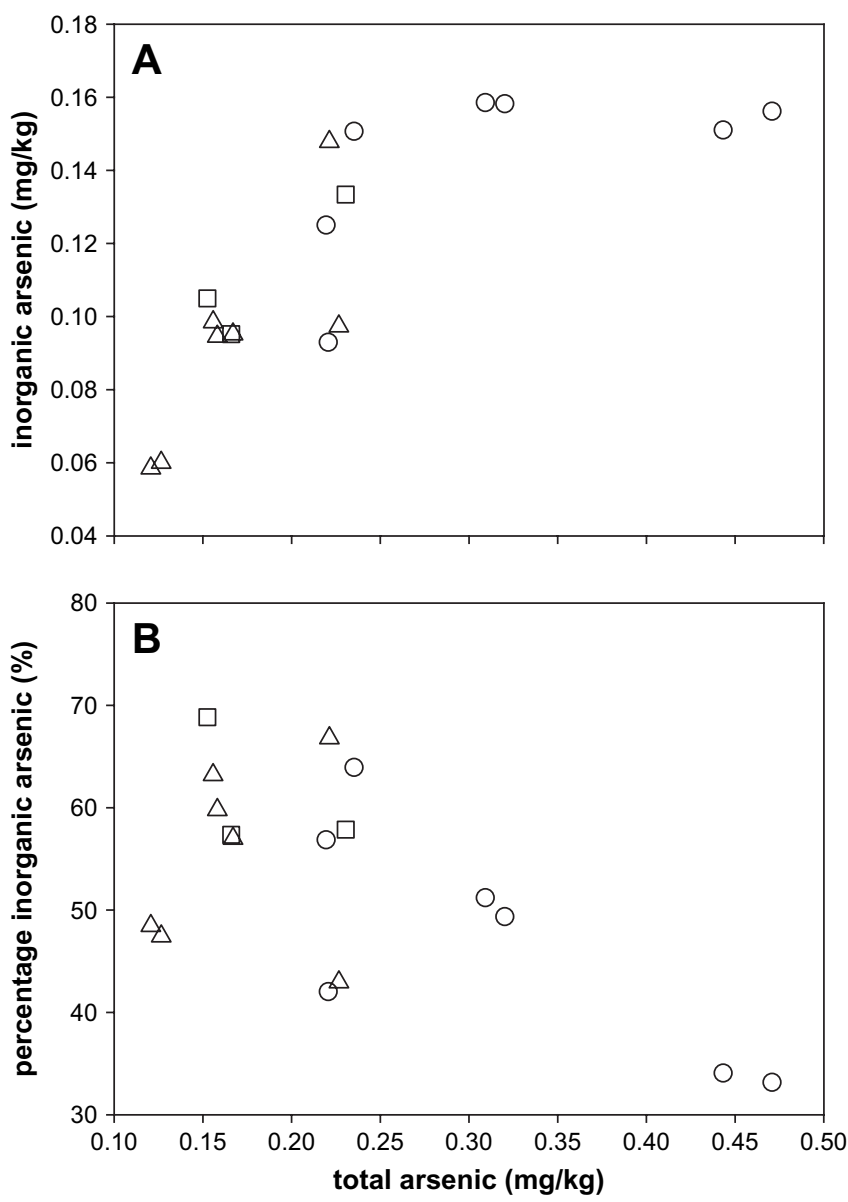

Fig. 1. Relationship between inorganic arsenic content (A) and percentage inorganic arsenic content (B) against total arsenic content of baby rice. Symbols refer to manufacturers in Table 1, triangles are for manufacturer (A), squares for (B) and circles for (C). as non-arsenic impacted regions of the Indian subcontinent (Williams et al., 2005, 2006), or low arsenic rice growing regions such as California in the US (Williams et al., 2007a) or Cadiz and Seville in Spain (Williams et al., 2007b), baby rice arsenic levels can be decreased dramatically. For example, on average, Indian basmati has 5-fold lower total arsenic, and 2.75 -fold lower inorganic arsenic than US produced rice (Williams et al., 2005). However, dominant US and EU rice producing regions, in general, have higher arsenic contents than other rice producing regions so far investigated (Williams et al., 2005, 2007a,b) with the exception of regions of SE Asia specifically affected by arsenic contaminated paddy soils (Williams et al., 2006). The reasons for these geographical differences in arsenic contents of rice are outlined in these Williams et al.'s series of papers.

An alternative approach to reducing infant exposure to arsenic is switching to other grain crops such as oat, barley, maize and wheat as a cereal carbohydrate/protein source. Williams et al. (2007b) found that aerobically grown crops, wheat and barley, were much less efficient at translocating arsenic to the grain than anaerobically grown rice, with grain total arsenic levels being an order of magnitude different for wheat and barley compared to rice.

It must also be remembered that it is not just pure and supplemented baby rice that are of concern. A wide range of other rice based products that are fed to babies, such as crackers, biscuits, crisped and puffed rice cereals, pasta, noodles, puddings, plain polished and whole grain rice, etc. (Mennella et al., 2006), are made primarily with, or are formulated with, rice. Thus powdered baby rice is only one component of babies' inorganic arsenic through rice.

\section{References}

Ackerman, A.H., Creed, P.A., Parks, A.N., Fricke, M.W., Schwegel, C.A., Creed, J.T., Heitkemper, D.T., Vela, N.P., 2005. Comparison of a chemical and enzymatic extraction of arsenic from rice and an assessment of the arsenic absorption from contaminated water by cooked rice. Environmental Science \& Technology 39, 5241-5246.

Council of the European Union, May 12, 1998. Council Directive 98/83/EC of November 1998 on the quality of water intended for human consumption. Official Journal European Community, L330/32-L330/52. http://eur-ex.europa. eu/LexUriServ/site/en/oj/1998/1_330/__33019981205en00320054.pdf.

Das, H.K., Mitra, A.K., Sengupta, P.K., Hossain, A., Islam, F., Rabbani, H.H., 2004. Arsenic concentrations in rice, vegetables, and fish in Bangladesh: a preliminary study. Environment International 30, 383-387.

Francesconi, K.A., 2007. Toxic metal species and food regulations - making a healthy choice. The Analyst 132, 17-20.

Gibson, R.S., Cage, L.-A., 1982. Changes in hair arsenic levels in breast and bottle fed infants during the first year of infancy. Science Total Environment 26, 33-40.

IARC, 2004. Some Drinking-Water Disinfectants and Contaminants, Including Arsenic, 84. IARC, Geneva.

Juhasz, A.L., Smith, E., Weber, J., Rees, M., Rofe, A., Kuchel, T., Sansom, L., Naidu, R., 2006. In vivo assessment of arsenic bioavailability in rice and its significance for human health risk assessment. Environmental Health Perspectives 114, 1826-1831.

Meacher, D.M., Menzel, D.B., Dillencourt, M.D., Bic, L.F., Schoof, R.A., Yost, L.J., Eickhoff, J.C., Farr, C.H., 2002. Estimation of multimedia inorganic arsenic intake in the US population. Human \& Ecological Risk Assessment 8, 1697-1721. 
Meharg, A.A., Williams, P.N., Schekel, K., Lombi, E., Feldmann, J., Raab, A., Zhu, Y-G., Gault, A., Islam, R., 2008. Speciation of arsenic differs between white and brown rice grain. Environmental Science \& Technology 42, 1051-1057.

Mennella, J.A., Ziegler, P., Briefel, R., Novak, T., 2006. Feeding infants and toddlers study: the types of foods fed to hispanic infants and toddlers. American Dietetic Association 106, S96-S106.

Meliker, J.R., Franzblau, A., Slotnick, M.J., Nriagu, J.O., 2006. Major contributors to inorganic arsenic intake in southeastern Michigan. International Journal Hygiene \& Environmental Health 209, 399-411.

National Research Council, 2001. Arsenic in Drinking-Water - 2001 Update. National Academy Press, Washington, D.C.

The Stationary Office, 1959. The arsenic in food regulations 1559 (S.I. 1959/ 831) as amended, London.

Tsuji, J.S., Yost, L.J., Barraj, L.M., Scrafford, C.G., Mink, P.J., 2007. Use of background inorganic arsenic exposures to provide perspective on risk assessment results. Regulatory Toxicological Pharmacology 48, 59-68.

USDA, 2006. Foreign Agricultural Service Global Agriculture Information Network Report CH6064. China, Peoples Republic of FAIRS Product Specific Maximum Levels of Contaminants in Foods.
WHO, 1993. Water Sanitation and Health. Guidelines for Drinking-water Quality, second ed. WHO, Geneva.

Williams, P.N., Price, A.H., Raab, A., Hossain, S.A., Feldmann, J., Meharg, A.A., 2005. Variation in arsenic speciation and concentration in paddy rice related to dietary exposure. Environmental Science \& Technology 39, 5531-5540.

Williams, P.N., Islam, M.R., Adomako, E.E., Raab, A., Hossain, S.A., Zhu, Y.G., Feldmann, J., Meharg, A.A., 2006. Increase in rice grain arsenic for regions of Bangladesh irrigating paddies with elevated arsenic in groundwaters. Environmental Science \& Technology 40, 4903-4908.

Williams, P.N., Raab, A., Feldmann, J., Meharg, A.A., 2007a. High levels of arsenic in South Central US rice grain: consequences for human dietary exposure. Environmental Science \& Technology 41, 21782183.

Williams, P.N., Villada, A., Deacon, C., Raab, A., Figuerola, J., Green, A.J., Feldmann, J., Meharg, A.A., 2007b. Greatly enhanced arsenic shoot assimilation in rice leads to elevated grain levels compared to wheat and barley. Environmental Science \& Technology 41, 6854-6859. 